KS. ARKADIUSZ DOMASZK SDB

Wydział Prawa Kanonicznego

Uniwersytetu Kardynała Stefana Wyszyńskiego w Warszawie

ORCID: 0000-0002-7118-3102

\title{
MISJE AD GENTES A NOWE WYZWANIA
}

Treść: Wstęp. - 1. Misje ad gentes. - 2. Migracje wyzwaniem misyjnym. - 2.1. Sytuacja migracyjna. - 2.2. Stanowisko Kościoła wobec migracji. - 2.3. Wybrane normy prawa kanonicznego. - 2.3.1. Biskupi Kościoła. - 2.3.2. Misjonarze. - 2.3.3. Jak ewangelizować? - 2.4. Migranci niechrześcijanie w optyce Erga migrantes caritas Christi. - 3. Nowe media a misyjność Kościoła. - Wnioski

\section{Wstęp}

Świat współczesny cechuje się wielkim dynamizmem zmian, także społecznych i kulturowych. Jednocześnie zauważa się rozwój prawa, które podąża za tymi przemianami. Podobne trendy występują w społeczności Kościoła katolickiego. Jednym z najważniejszych zadań tej wspólnoty jest głoszenie orędzia wiary opartego na objawieniu Jezusa Chrystusa. Jest to inaczej mówiąc nakaz misyjny, skierowany do wszystkich ludzi (ad gentes), który realizują, tak cały Kościół, jak i poszczególni wierni. Zadanie ewangelizacji jest w pewnej części unormowane prawem kanonicznym. Prawo to powinno zauważyć nowe sytuacje społeczne, które są powiązane z nakazem misyjnym. Chodzi m.in. o zagadnienie nowych i licznych migracji ludzi: niechrześcijan. Innym wyzwaniem są mass media, które znacząco oddziałują na ludzkie zachowania i postawy, co także należy postrzegać w kontekście nowych wyzwań dla misji ad gentes. Prawo podąża za życiem, więc należy zbadać, jak prawo kanoniczne dostosowuje się do 
tych nowych sytuacji. Kto i w jaki sposób podejmuje odnośne działania ad gentes, na podstawie jakich norm kanonicznych? W jakich nowych formach i metodach głosi się Ewangelię we współczesnym społeczeństwie?

Podstawowym punktem wyjścia dla dalszych rozważań jest nakreślenie, czym są misje ad gentes, według obowiązującego prawa kanonicznego. W kolejnym punkcie będzie przybliżone zjawisko współczesnej migracji oraz reakcji Kościoła na tę sytuację, zwłaszcza wobec niechrześcijan w środowisku europejskim. Następnie treść opracowania zakreśli sytuację tzw. nowych mediów, ich oddziaływanie oraz ewangelizację podejmowaną przez ludzi Kościoła w przestrzeni medialnej. Opracowanie będzie próbą odpowiedzi na pytania: czy istniejące normy prawa kanonicznego przystają do aktualnej rzeczywistości, czy należy postulować wskazanie unormowań de lege ferenda.

\section{Misje ad gentes}

Kościół katolicki posłuszny poleceniu Jezusa Chrystusa zawsze głosił Ewangelię. Praktyczne formy realizacji zadania misyjnego oraz zakreślenie adresatów oddziaływania ulegało ewolucji w ciągu dziejów Kościoła. Nadal jeszcze określa się niektóre tereny i kraje, jako tzw. tereny misyjne. To jest tam, gdzie misja ad gentes kieruje się do ludzi i społeczności, nie znających Ewangelii. Aktualnie, obok tego tradycyjnego wyróżnienia zauważa się obszary, wcześniej chrześcijańskie, gdzie liczne grupy wiernych utraciły sens wiary i są dalekie od Chrystusa ${ }^{1}$. W tych krajach lub środowiskach potrzebne są działania, które nazywa się nową ewangelizacją lub inaczej reewangelizacją.

We współczesnym świecie, m.in. na skutek procesu globalizacji, tradycyjne podziały środowisk, które wymagają działań misyjnych Kościoła, ulegają zmianie. Dotyczy to także zjawiska migracji. Aby odpowiedzieć na pytanie, jak ewangelizować w środowiskach migrantów: niechrześcijan, najpierw należy wyjaśnić, czym są misje ad gentes.

${ }^{1}$ Por. Jan PaweŁ II, Encyklika Redemptoris missio, 07.12.1990, Poznań 1991, nr 33. 
Działalność misyjną określa się przede wszystkim, jako ewangelizację osób niewierzących, tj. tych, którzy nie znają Jezusa Chrystusa i nie przyjęli wiary chrześcijańskiej. Działalność tę podejmowano zwłaszcza na terenach zwanych misyjnymi, gdzie ma miejsce ewangelizacja narodów ${ }^{2}$. W tym dziele współuczestniczą wszyscy wierni, co Kościół wyraża także w swoim prawie: „Ponieważ cały Kościół jest ze swej natury misyjny, a dzieło ewangelizacji winno być uznane za fundamentalny obowiązek Ludu Bożego, stąd wszyscy wierni, świadomi swojej odpowiedzialności, winni wnosić swój udział w dzieło misyjne"3. Zadanie to jest ciągle aktualne skoro wierni należący do Kościoła katolickiego stanowią jedynie ok. 18 \% populacji świata, tj. 1.300000000 ludzi (według danych statystycznych na koniec 2015 r.) ${ }^{4}$.

Współczesne migracje ludzi powodują to, że do krajów postrzeganych w historii jako chrześcijańskie docierają liczni niechrześcijanie. Dlatego działania misyjne są potrzebne nie tylko na odległych terytoriach misyjnych. Należy tę rzeczywistość najpierw dostrzec. Tak pasterze jak i liczni wierni świeccy winni sobie uświadomić

${ }^{2}$ Por. E. Sztafrowski, Podręcznik prawa kanonicznego, t. 3, Warszawa 1986, s. 42.

${ }^{3}$ Codex Iuris Canonici, auctoritate Joannis Pauli PP. promulgatus, Kodeks Prawa Kanonicznego. Przekład polski zatwierdzony przez Konferencję Episkopatu (=KPK 1983), Poznań 1984, kan. 781; por. Concilium Vaticanum II, Decretum Ad gentes (=Ad gentes), 07.12.1965, AAS 58(1966), s. 947-990, tekst polski w: Sobór Watykański II, Konstytucje, Dekrety, Deklaracje, Poznań 2002, s. 433-471, nr 2; La Chiesa è missionaria. La ricezione nel Codice di Diritto Canonico, red. L. Sabbarese, Roma 2009; J.A. Yawovi, L'azione missionaria della Chiesa ieri e oggi, Venezia 2015; S. KASPRZAK, Prawno kanoniczne implikacje nakazu misyjnego, Roczniki Nauk Prawnych 25(2015)2, s. 129-142; P.A. SoKoŁowsKi, Teologiczna interpretacja „naturalnej misyjności Kościoła”, w: Misje i religie. Księga pamiątkowa poświęcona ks. prof. dr. hab. Władysławowi Kowalakowi z okazji 45-lecia działalności misjologii w ATK i UKSW w Warszawie, red. J. Różański, Górna Grupa 2014, s. 61-93; V. DE PAOLIs, La Chiesa missionaria e il Codice del Concilio, w: La Chiesa è missionaria. La ricezione nel Codice di Diritto Canonico, red. L. Sabbarese, Città del Vaticano 2009, s. 17-55.

${ }^{4}$ Por. Statystyki Kościoła: na świecie wzrasta liczba katolików, https://stacja7.pl/ ze-swiata/statystyki-kosciola-swiecie-wzrasta-liczba-katolikow/ [dostęp 9.10.2018]. 
postępujące zmiany, aby podjąć dalsze działania ewangelizacyjne $e^{5}$. Trzeba stwierdzić, że w dotąd chrześcijańskim środowisku żyją coraz liczniejsze społeczności niechrześcijan.

Magisterium Kościoła konstatuje te zmiany w dokumencie $R e$ demptoris missio, ale również w innych wypowiedziach. „Europa potrzebuje wiarygodnych ewangelizatorów (...). Dziś bardziej niż kiedykolwiek konieczne jest, aby każdy chrześcijanin miał świadomość misyjną, począwszy od biskupów, prezbiterów, diakonów, osób konsekrowanych, katechetów i nauczycieli religii (...)" ${ }^{\prime 6}$ Katolicy dostrzegają nieochrzczonych pośród swoich społeczności. Jednakże problematyka ewangelizacyjna dotyczy także rodzin, w których rodzice: katolicy nie zadbali o chrzest swoich dzieci. Znaczna liczba dzieci nieochrzczonych - często ze względu na obojętność religijną ich rodzin - oznacza, że Europa jest również przestrzenią pierwszej ewangelizacji i wymaga podjęcia misji ad gentes ${ }^{7}$.

\footnotetext{
${ }^{5}$ Por. W. Necel, Imigranci $w$ Polsce - kultura przyjęcia, Prawo Kanoniczne 58(2015) nr 3, s. 87-89; s. KAsPRZAK, Prawno kanoniczne implikacje nakazu misyjnego, s. 142-145; P.A. Sокоєошsкi, „Misje” a „Europa”-zarys problematyki, w: Działalność misyjna i promocja ludzka. Teoria i praktyka eklezjalna, red. J. Stala, Lublin 2011, s. 251-254; G. TAssello, Accoglienza/ospitalità nella pastorale, w: Migrazioni. Dizionario socio-pastorale, red. G. Battistella, Milano 2010, s. 15-18; C. Lussi, La missione della Chiesa nel contesto della mobilità umana, Città del Vaticano 2005, s. 63-82; N. Comnolly, Ad gentes to Evangelii Gaudium: Mission's Move to the Centre, The Australasian Catholic Record 92(2015)4, s. 387-402.

${ }^{6}$ Jan PAweŁ II, Adhortacja apostolska o Jezusie Chrystusie, który żyje w Kościele, jako źródło nadziei dla Europy Ecclesia in Europa, 28.06.2003, Kraków 2003, nr 49; nr 64.

${ }^{7}$ Por. tamże, nr 46; J.A. BArreda, Missione, w: Migrazioni. Dizionario socio-pastorale, red. G. Battistella, Milano 2010, s. 666-676; M. FiaŁkowski, Niewierzacy i obojętni religijnie wyzwaniem dla Kościoła w Polsce, Ateneum Kapłańskie 165(2015), z. 2(639), s. 229-237; D. Lipiec, Duszpasterstwo parafialne wobec współczesnych wyzwań, tamże, s. 238-251. Por. także Komitet ds. Dialogu z Niewierzącymi Rady Konferencji Episkopatu Polski ds. Dialogu Religijnego, Niewierzacy w parafii - sugestie duszpasterskie, Wiadomości KAI 27(1999), 08.07.1999, s. 19-21; P. Poupard, Ewangelizacja we współczesnym świecie, L'Osservatore Romano (pol.) 25(2004)5, s. 39-41.
} 
Dostrzeżenie aktualnych wyzwań misyjnych w kontekście europejskim, ponownie domaga się postawy odwagi i przywoływania wspaniałych przykładów z przeszłości. Chodzi o odwagę, która „pobudzała misjonarzy przeszłości, tej samej gotowości do słuchania głosu Ducha Świętego" ". Należy zauważyć, że w początkach historii Kościoła, misja wśród narodów była zadaniem każdego z wiernych, niezależnie od wyodrębniającej się posługi misjonarzy, „była w istocie uważana za normalny owoc życia chrześcijańskiego, codzienne zadanie dla każdego wierzącego poprzez świadectwo osobiste i wyraźne przepowiadanie, tam, gdzie to było możliwe"

Celem działalności misyjnej jest doprowadzenie każdego człowieka do Chrystusa. Istnieje też cel obejmujący budowanie społeczności. Zaangażowanie misyjne tworzy wspólnotę kościelną, tak, aby zaszczepić Ewangelię wśród narodów i społeczności, które nie wierzą w Chrystusa. Powstające wspólnoty chrześcijańskie z czasem współtworzą samodzielne i dojrzałe rodzime Kościoły partykularne ${ }^{10}$. Oczywiście w sytuacji europejskiej struktury kościelne już istnieją i posiadają długą tradycję, ale wymagają ożywienia duchem apostolskim. Szczególnym rysem misyjnej działalności Kościoła jest chrystocentryzm. Posługa kościelna kieruje osoby i całe społeczności do Chrystusa, gdyż tylko Jezus jest jedynym Zbawicielem i Pośrednikiem między Bogiem a ludźmi ${ }^{11}$.

Ewangelizacja, czy podejmowana na terenach misyjnych, czy gdy kieruje się do imigrantów, domaga się wolności wyboru. Przyjęcie wiary w Chrystusa jest propozycją, która nie może być narzucana. Z tych zasadniczych powodów Kościół katolicki przyjmuje koncepcję wolności sumienia, ale jednocześnie wskazuje na moralny obowiązek poszukiwania prawdy, także prawdy religijnej ${ }^{12}$. Wybór wiary

\footnotetext{
${ }^{8}$ Jan Pawe $\mathrm{II}$, Redemptoris missio, nr 30.

9 Tamże, nr 27.

${ }^{10}$ Por. Ad gentes, nr 6; A. Reuter, The Missionary Activity of the Church (Canons 781-792), Studia Canonica 23(1989)2, s. 387-407.

${ }^{11}$ Por. Ad gentes, nr 3; Jan Pawee II, Redemptoris missio, nr 4-6.

${ }^{12}$ Por. tamże, nr 8; Concilium Vaticanum II, Declaratio de libertate religiosa Dignitatis humanae, 07.12.1965, AAS 58(1966), s. 929-946, nr 2.
} 
katolickiej, dokonany przez człowieka jest odkryciem nowości życia zanurzonego w Chrystusie; stanowi odpowiedź na zbawczą wolę Boga; oraz jest uznaniem prawdy o Bogu ${ }^{13}$. Ponadto osoba ludzka poprzez poznanie Chrystusa odkrywa rzeczywistą prawdę o swoim losie i powołaniu ${ }^{14}$.

Działalność misyjną podejmują poszczególni ludzie, ale również wspólnoty katolickie. Jednakże Kościół jest przekonany, że przede wszystkim Duch Święty jest Tym, Który pobudza społeczność kościelną do działania ${ }^{15}$. Duch Święty, jako główny sprawca misji, kieruje tą posługą i każdemu z ludzi daje możliwość poznania Boga i Jego paschalnej tajemnicy ${ }^{16}$. Natomiast wspólnota kościelna, będąca znakiem i narzędziem zbawienia, jest narzędziem Chrystusa i Ducha Świętego. Poprzez posługę misyjną orędzie zbawienia dociera do wszystkich ludzi; a Kościół jest świadomy tego, że tej misji nie może zaprzestaćc ${ }^{17}$. Przywołane w tym punkcie założenia doktrynalne należy przełożyć na praktykę, aby z odwagą, tak całej wspólnoty Kościoła, jak i poszczególnych katolików, skonfrontować je z aktualnymi wyzwaniami, które stoją przed Kościołem ${ }^{18}$.

\section{Migracje wyzwaniem misyjnym}

\subsection{Sytuacja migracyjna}

Przemieszczanie się ludzi nieustannie ma miejsce na każdym kontynencie. Choćby przywołać można medialnie nagłaśniane wydarzenie o tłumie kilkutysięcznym zmierzającym z krajów latynoskich do USA, w listopadzie 2018 r. Oczywistym jest fakt, że ludzie od wieków wędrowali do innych krajów czy na inne kontynenty. Nie

\footnotetext{
${ }^{13}$ Por. Ad gentes, nr 7.

${ }^{14}$ Por. tamże, nr 8.

${ }^{15}$ Por. tamże, nr 4; Jan Pawe£ II, Redemptoris missio, nr 21-30.

${ }^{16}$ Por. tamże, nr 28.

${ }^{17} \mathrm{O}$ misyjnej roli Kościoła, por. tamże, nr 9-11; Ad gentes, nr 5.

${ }^{18}$ Por. F. Filoni, Attualità della Missione „Ad Gentes”, w: Il Camino della missione. Convegno Internazionale a cinquant'anni dalla promulgazione del Decreto Conciliare Ad Gentes, red. A. Trevisiol, Roma 2015, s. 503-513.
} 
jest to niczym nowym, ale powszechnym zjawiskiem społecznym i kulturowym, istniejącym od samych początków historii człowieka. We współczesnym kontekście, jednym z ważniejszych kierunków migracji nadal jest Europa. Ten trend nasilił się zwłaszcza od roku 2015, w którym Angela Merkel kanclerz Republiki Federalnej Niemiec w publicznych wypowiedziach medialnych zaprosiła migrantó $w^{19}$ do Europy. Od tego roku migracja na kontynent europejski, a zwłaszcza do Unii Europejskiej, choć wcześniej także miała miejsce, to jednak znacząco się nasiliła ${ }^{20}$. Niekontrolowany napływ wielkiej liczby ludzi do Europy jest nowym wyzwaniem politycznym i gospodarczym, czy społecznym. Również jest postrzegane jako zagrożenie.

Migrację najczęściej postrzega się w dwóch odsłonach, jako emigrację i imigrację $e^{21}$. Pierwsza forma charakteryzuje się opuszczeniem ojczystego kraju przez pojedyncze osoby, rodziny, jak i większe grupy, jako wychodźstwo (ekonomiczne lub polityczne). Druga forma oznacza przyjazd do obcego kraju, często celem osiedlenia się tam na dłuższy czas lub na stałe. Ponadto występuje także migracja osób wewnątrz poszczególnych krajów (kontynentów czy Unii Europejskiej). Migracja jest zjawiskiem bardzo złożonym i obejmuje różne aspekty, jak: historyczno-geograficzne, prawne, socjologiczne i religijne ${ }^{22}$.

${ }^{19}$ Powszechnie używane słowo: migranci należy różnicować, kiedy mowa jest o uchodźcach, np. wojennych, a odrębnie wobec osób migrujących głównie z przyczyn ekonomicznych.

${ }^{20}$ Por. O. Forti, E. VArinetti, Annus horribilis, Orientamenti Pastorali (2015)10, s. $13-24$.

${ }^{21}$ Por. P. TAras, Emigracja, w: Encyklopedia Katolicka, t. 4, red. R. Łukaszyk, L. Bieńkowski, F. Gryglewicz, Lublin 1995, kol. 942-945; F. Timmermans, Uchodźcy, w: Misjologia. Kontekst ekumeniczny, Mały słownik, red. J. Bria, P. Chanson, J. Gadille, M. Spindler, tłum. A. Kuryś, Warszawa 2007, s. 395-400.

${ }^{22}$ Por. M.R. Górniak, Migracja - aspekt historyczno-geograficzny, w: Encyklopedia Katolicka, t. 12, red. S. Wilk, E. Ziemann, Lublin 2008, kol. 953-955; Z. SKwiERCZy Ński, Migracja - aspekt prawny, tamże, kol. 955-957; M.R. GóRNiAK, Z. SKWIERCZYŃski, J. Mariański, Migracja - aspekt socjologiczny, tamże, kol. 957-960; R. URBAŃCZYK, Z. SKWIERCZyŃski, Migracja - aspekt teologiczny, tamże, kol. 960-962; L. Hernández Mercado, Urbanización, migración y globalización. 
Do migracji najczęściej skłaniają przyczyny natury ekonomicznej: ubóstwo kraju czy regionu pochodzenia migranta ${ }^{23}$, brak pracy i perspektyw rozwoju, wojny, konflikty, prześladowania polityczne, etniczne lub religijne, czy także kataklizmy naturalne ${ }^{24}$. Na skutek tego rodzaju wydarzeń i uwarunkowań migranci lub uchodźcy przemieszczają się do krajów albo regionów zamożniejszych gospodarczo, ustabilizowanych politycznie, dających perspektywę rozwoju i spokojnego życia. Taką przestrzenią dla wielu jawi się Europa. Jednakże napływ imigrantów, zwłaszcza jeśli jest masowy, przyczynia się z jednej strony do pozytywnych zmian w kraju docelowym, ale też z drugiej może się stać przyczyną konfliktów i problemów, natury gospodarczej, społecznej, politycznej, a nawet religijnej. Integracja ludności napływowej ze społeczeństwem docelowym jest długotrwała i nie zawsze owocna. Przykładowo, Szwecja przez dziesięciolecia przyjmowała migrantów, uruchamiała programy asymilacyjne, a mimo to na początku XXI wieku mówi się o enklawach islamskich w wielu miastach szwedzkich, gdzie ważniejsze jest stosowanie prawa szariatu niż prawa państwowego. Jest to sytuacja nieformalna, istnieniu takich stref zaprzecza dyplomacja szwedzka, jednak są one faktem, na co wskazują doniesienia publicystyczne ${ }^{25}$.

W związku z tym, państwa docelowej migracji sterują przepływem ludzi, na podstawie własnego prawa wewnętrznego lub zawartych umów międzynarodowych. W ten sposób określa się np. kwestie zasad pobytu stałego lub czasowego, przyznania opieki prawnej, prawa azylu itp. Ustawodawstwo państwowe może różnicować przybyszów, przyznawać prawa lub je odmawiać, w zależności od politycznych czy

Tres fenómenos de nuestro tiempo: causas y efectos, Revista Mexicana de Derecho Canónico 20(2014)1, s. 24-38.

${ }^{23}$ Por. Jan Pawee II, Redemptoris missio, nr 37.

${ }^{24}$ Por. M.R. GóRniak, Migracja - aspekt historyczno-geograficzny, kol. 953-955; O. Forti, E. Varinetti, Annus horribilis, s. 15-19.

${ }^{25}$ Por. S. Żaryn, Kpili z Kaczyńskiego, teraz przyznają: „jest 50 stref 'no-go' w Szwecji", https://wpolityce.pl/polityka/265869-kpili-z-kaczynskiego-teraz-przyznaja-jest-55-stref-no-go-w-szwecji-debata-ws-imigrantow-to-dowod-ze-media-mainstreamowe-prowadza-wroga-wobec-polski-dzialalnosc [dostęp 26.11.2018]. 
ekonomicznych interesów przyjmującej społeczności, wskazywać na preferowane zawody, poziom wykształcenia, określać limity pozytywnie rozpatrzonych wniosków o przyjęcie.

Ponadto trzeba przypomnieć, że istnieją zapisy w prawie międzynarodowym, które przeciwstawiają się wszelkim formom dyskryminacji ludzi migrujących i gwarantują im prawo do przemieszczania się. Zagadnienia migracyjne i mobilność ludzi podejmują m.in. takie akty jak: Powszechna deklaracja praw człowieka ONZ (1948), Międzynarodowy pakt praw obywatelskich i politycznych ONZ (1966), Międzynarodowa konwencja w sprawie likwidacji wszelkich form dyskryminacji rasowej (1966) czy Karta praw podstawowych Unii Europejskiej (2000) ${ }^{26}$.

W ostatnich latach znacząco wzrosła imigracja do Europy. Jak wielka jest to liczba? Trudno do końca powiedzieć. Stanowi to także problem dla nauk socjologicznych, czy dla instytucji rządowych, odpowiedzialnych za sektor ochrony granic lub nadzór statystyczny. Również dlatego, że znaczna część imigrantów dociera do krajów Unii Europejskiej nielegalnie, stąd oficjalne statystyki są zawodne. Jeszcze kilkanaście lat wcześniej (przed 2000 r.), przypuszczalne dane sugerowały rząd 5-8 mln ludzi na terenie Europy, tj. tych, którzy nie posiadali uregulowanej sytuacji prawnej ${ }^{27}$. Ta liczba corocznie się zwiększa, ze względu na stały napływ nowych imigrantów. W roku 2013 skala migracji w Unii Europejskiej (do/z) sięgała $3.4 \mathrm{mln}$ ludzi, z czego 1.7 mln ludzi pochodziło z państw nieczłonkowskich ${ }^{28}$. Odpowiedni poziom migracji w 2014 r. wyniósł 3.8 mln ludzi, w tym $1.9 \mathrm{mln}$

\footnotetext{
${ }^{26}$ Por. Z. Skwierczyński, Migracja - aspekt prawny, kol. 956; Benedykt XVI, Encyklika Caritas in veritate, 29.06.2009, Kraków 2009, nr 62.

${ }^{27}$ Por. A. Domaszk, Nowe horyzonty misji „Ad gentes”-normy prawa kanonicznego, Prawo Kanoniczne 53(2010) nr 1-2, s. 31-32. Możliwa roczna liczba ludzi przemycanych do Unii Europejskiej w r. 1999: ok. 400 tys.

${ }^{28}$ Por. Eurostat, Statystyki dotyczace migracji i populacji migrantów, http:// ec.europa.eu/eurostat/statistics-explained/index.php/Migration_and_migrant_population_statistics/pl [dostęp 23.08.2016].
} 
z państw nieczłonkowskich ${ }^{29}$ a w 2015 r. 4.7 mln ludzi, w tym $2.7 \mathrm{mln}$ ludzi z państw nieczłonkowskich, wśród tych ostatnich są także ci, którzy posiadają obywatelstwo jednego z krajów członkowskich ${ }^{30}$.

Badania statystyczne nie zawsze obejmują całość zjawiska, zwłaszcza, że w części jest ono nielegalne. Rok 2015 i 2016 oraz 2017 przyniósł ze sobą napływ do Europy olbrzymich mas ludzkich, w tym także osób, których takie badania nie obejmują. Medialne doniesienia wskazywały na liczby nielegalnych migrantów przekraczające milion osób rocznie (2015 i 2016). Prawdopodobnie w roku 2018 ten poziom migracji zmniejszył się, również z powodu przeciwdziałania, podjętego przez część krajów Unii Europejskiej, czy także zahamowania przepływu ludzi przez Turcję.

Olbrzymi napływ imigrantów zasadniczo kieruje się do krajów Zachodniej Europy, głównie Niemiec, Francji oraz Wielkiej Brytanii, która w ramach tzw. brexitu opuszcza tę wspólnotę, co ma nastąpić w marcu 2019 r. Wielu migrantów wybierając cel swej drogi, kieruje się uproszczonymi wizjami o bogactwie wymienionych krajów, ich otwartości i zabezpieczeniu socjalnym. Także wtedy, gdy przekroczenie granicy Unii Europejskiej nastąpiło, np. w jednym z krajów położonych nad Morzem Śródziemnym (Grecja, Włochy, Hiszpania), czy niezależnie od wniosków o azyl, złożonych w pierwszym państwie, po przejściu wymienionej granicy, np. w Polsce.

Wskaźniki ekonomiczne dla Polski w latach 2017-2019 znacząco wzrosły, co z czasem mogą zauważyć migranci i co spowoduje, że Rzeczpospolita stopniowo przestanie być jedynie krajem tranzytowym, a zacznie przyciągać tzw. kapitał ludzki. Częściowym punktem odniesienia są badania prowadzone przez Polski Główny Urząd Statystyczny. Według danych z 2008 r. dotyczących imigracji w Polsce,

\footnotetext{
${ }^{29}$ Por. Eurostat, Migration and migrant population statistics, http://ec.europa.eu/ eurostat/statistics-explained/index.php/Migration_and_migrant_population_statistics [dostęp 23.08.2016].

${ }^{30}$ Por. Eurostat, Statystyka dotyczaca migracji i populacji migrantów, http:// ec.europa.eu/eurostat/statistics-explained/index.php/Migration_and_migrant_population_statistics/pl\#Wi.C4.99cej_informacji_z_Eurostatu [dostęp 6.09.2017], dane statystyczne $\mathrm{z}$ marca 2017.
} 
stwierdzono, że największą grupę stanowili wówczas imigranci z Ukrainy, Białorusi i Chin; najczęstszą przyczyną ich przyjazdu była nauka, a dla $1 \frac{1}{3}$ praca zarobkowa ${ }^{31}$. Liczbę imigrantów zagranicznych napływających do Polski na okres 12 miesięcy i więcej (długookresowa migracja, ze wszystkich krajów, nie tylko Unii Europejskiej) Główny Urząd Statystyczny obliczył w roku 2013 na: 43404, a w 2014 na: 46129 osób $^{32}$.

Rzeczywiste liczby osób migrujących do Polski są trudne do oszacowania, także ze względu na nielegalny sposób ich dotarcia oraz dalszy niezalegalizowany pobyt. Badania statystyczne stanowią dane kierunkowe. W ostatnich dziesięcioleciach jedną $\mathrm{z}$ większych fal migracji, która przybyła do Polski: pochodziła z Czeczeni, skąd po konfliktach zbrojnych w latach 90 . wyemigrowało do Polski ok. 80 tys. Czeczenów. Większość z nich wyjechała do innych krajów Zachodniej Europy; możliwe, że aktualnie mieszka ich w Polsce poniżej 10 tys. ${ }^{33}$ Natomiast społecznością narodowościową wyróżniającą się swą masą są Wietnamczycy. Dane Głównego Urzędu Statystycznego nie obejmują rzeczywistej ich liczby. Być może jest ich w Polsce nie 20 tys., ale ok. 40 tys. osób ${ }^{34}$. Jednakże nadal największą liczbą wyróżniają się Ukraińcy. Szacuje się, że w 2016 mogło ich przybyć do Polski od 1,2 do 1,5 mln., podobnie w kolejnych latach. Należy tu dodać, że zdecydowana ich większość przyjeżdża do Polski z powodów

\footnotetext{
${ }^{31}$ Por. GŁówny Urząd Statystyczny, Informacja o badaniach zasobów imigracyjnych $w$ Polsce $w 2008$ r., http://stat.gov.pl/cps/rde/xbcr/gus/lud_infor_o_badan_zasob_imigr_pl_w_2008.pdf [dostęp 6.09.2017].

${ }^{32}$ Por. Tenże, Rocznik Statystyczny Rzeczypospolitej Polskiej 2015, [dostęp 23.08.2016], s. 224; Tenże, Rocznik Demograficzny 2015, [dostęp 23.08.2016], s. $451-481$.

${ }^{33}$ Por. Polska przyjęła już ponad 80 tysięcy Czeczenów i wciąż przyjmuje następnych. Czy komuś to przeszkadza?, http://natemat.pl/155107,polska-przyjela-juz-blisko-90-tysiecy-uchodzcow-z-czeczenii-dzis-zostala-ich-tylko-garstka-bo-nie-chcieli-u-nas-zostac [dostęp 24.08.2016].

${ }^{34}$ Por. Wietnamczycy $w$ Polsce, http://pl.wikipedia.org/wiki/Wietnamczycy_w_ Polsce [dostęp 23.08.2016]. O duszpasterstwie wśród Wietnamczyków mieszkających w Polsce, por. E. Osıecki, Misje u progu naszych domów, w: Ecclesia in Asia. Wybrane problemy Kościoła, red. J. Różański, Warszawa 2004, s. 177-179.
} 
ekonomicznych (migranci ekonomiczni). Podejmują pracę najczęściej okresową (od 3 miesięcy do 3 lat) i wracają do swojej ojczyzny. Swobodne przekraczanie granicy ułatwiło także zniesienie obowiązku wizowego w 2017 r. dla obywateli Ukrainy wjeżdżających do Unii Europejskiej, jeśli tylko posiadają odpowiedni paszport i środki finansowe na czas pobytu.

\subsection{Stanowisko Kościoła wobec migracji}

Kościół katolicki zauważa zjawisko migracji i akcentuje przede wszystkim przyrodzoną godność każdej osoby ludzkiej ${ }^{35}$. To jest punkt wyjścia dla dalszej refleksji. Myśl chrześcijańska widzi w każdym z tych ludzi obraz Chrystusa, który urodził się w trakcie podróży, uciekał do Egiptu i doświadczał trudów wędrowania. Chrześcijanie powinni więc okazywać migrantom szacunek, gościnność, solidarność, współczucie i miłosierdzie ${ }^{36}$. Myśl ta nawiązuje m.in. do licznych wskazań Starego Testamentu, którego treść obligowała do uszanowania cudzoziemców. By przywołać np. słowa z Księgi Wyjścia: „Nie będziesz gnębił i nie będziesz uciskał cudzoziemców, bo wy sami byliście cudzoziemcami w ziemi egipskiej” (Wj 22,20).

Troska o migrantów była wielokrotnie wyrażana w dokumentach kościelnych, np. w konstytucji papieża Piusa XII Exsul Familia ${ }^{37}$. Jan XXIII wskazywał na potrzeby uchodźców oraz obowiązki państw; na prawo człowieka do udania się do innych krajów, m.in. by zaspokoić potrzeby własne i swojej rodziny, czy na konieczność ochrony społecznej względem migrantów ${ }^{38}$. Dalej trzeba wskazać dokumenty

\footnotetext{
${ }^{35}$ Por. JoAnnes XXIII, Litterae encyclicae Pacem in terrris, 11.04.1963, AAS 55 (1963), s. 257-304, nr 9.

${ }^{36}$ Por. R. Urbańczy K, Z. Skwierczyński, Migracja - aspekt teologiczny, kol. 960-961; s. FERdinANDI, Il volto di una parrocchia ospitale: competenze spirituali, requisiti sociali, collaborazione col territorio, Orientamenti Pastorali (2015)10, s. 25-31.

${ }^{37}$ Por. PIUs XII, Constitutio apostolica Exsul Familia, 01.08.1952, AAS 44(1952), s. 649-704.

${ }^{38}$ Por. JoAnnes XXIII, Pacem in terris, nr 25, 103-108.
} 
Soboru Watykańskiego II: konstytucję Gaudium et spes ${ }^{39}$, czy dekret Ad gentes $^{40}$. Dokumentami posoborowymi były: motu proprio Pawła VI: Pastoralis migratorum cura z $1969 \mathrm{r}^{41}$ oraz instrukcja Kongregacji Biskupów De pastorali migratorum cura $\mathrm{z}$ tego samego roku ${ }^{42}$.

Tematykę migracji aktywnie podejmuje Stolica Apostolska ${ }^{43}$. Organem odpowiedzialnym, w tym zakresie, wcześniej była Papieska Rada Duszpasterstwa Migrantów i Podróżnych ${ }^{44}$, która wydała szereg dokumentów, a zwłaszcza instrukcję z 2004 r.: Erga migrantes caritas Christi ${ }^{45}$. Papież Franciszek Listem apostolskim Humanam progressionem z 2016 r. połączył: Papieską Radę Iustitia et Pax, Papieską Radę Cor unum, Papieską Radę ds. Duszpasterstwa Migrantów i Podróżujących oraz Papieską Radę ds. Duszpasterstwa Służby Zdrowia. W ten sposób zespolono wysiłki Kościoła, aby w pełni służyć integralnemu

${ }^{39}$ Por. Concilium Vaticanum II, Constitutio Gaudium et spes, 07.12.1965, AAS 58(1966), s. 1025-1115, nr 14, 53, 58.

${ }^{40}$ Por. Ad gentes, nr 6.

${ }^{41}$ Por. Paulus VI, Litterae apostolicae motu proprio Pastoralis migratorum cura, 15.08.1969, AAS 61(1969), s. 600-603.

${ }^{42}$ Por. SaCra Congregatio pro Episcopis, Instructio De pastorali migratorum cura, 22.08.1963, AAS 61(1969), s. 614-643; W. Necel, Prawo migranta do specjalnego duszpasterstwa, Warszawa 2012, s. 23-75.

${ }^{43}$ Por. H. Stawniak, Problematyka migracji ludności w świetle zasad i niektórych działań Stolicy Apostolskiej, Seminare 26(2009), s. 143-157; P. KolasA, Ochrona praw uchodźców w Unii Europejskiej w świetle wytycznych Stolicy Apostolskiej, Warszawa 2010; G. Tassello, Migranti soggetti di diritto. Gli insegnamenti della Santa Sede, w: Congregazione per L’Educazione Cattolica, Pontificia Commissione Migrazioni e Turismo, Orizzonti pastorali oggi, Studi interdisciplinari sulla mobilità umana, $2^{\text {a }}$ edizione, Padova 1987, s. 25-38.

${ }^{44}$ Por. Papieska Rada Duszpasterstwa Migrantów i Podróżnych, Instrukcja Erga migrantes caritas Christi, 03.05.2004, Wrocław 2007, nr 31-33; JoAnnes PAulus II, Constitutio apostolica de Romana Curia Pastor Bonus, 28.06.1988, AAS 80 (1988), s. 841-912, art. 149-151; A. Benlloch PovedA, La nuova legislazione canonica sulla mobilità sociale, w: Pontificio Consiglio della Pastorale per i Migranti e GLi ITINERANTi, Migrazioni e diritto ecclesiale. La pastorale della mobilità umana nel nuovo Codice di diritto canonico, Padova 1992, s. 9-22.

${ }^{45}$ Por. W. Necel, Prawno-duszpasterskie dyspozycje instrukcji Erga Migrantes Caritas Christi, Prawo Kanoniczne 52(2009) nr 3-4, s. 51-68. 
rozwojowi ludzkiemu. Nowa struktura Kurii Rzymskiej: Dykasterium ds. Integralnego Rozwoju Człowieka ma służyć osobom migrującym, potrzebującym, chorym i wykluczonym, zmarginalizowanym, ofiarom konfliktów zbrojnych oraz katastrof naturalnych, więźniom, bezrobotnym i ofiarom jakiejkolwiek formy niewolnictwa i tortury ${ }^{46}$.

W myśli Kościoła nt. migracji podkreśla się wymiar duchowy i pastoralny tego zagadnienia ${ }^{47}$. Chrześcijanie dostrzegają w migrantach obraz Chrystusa, który powiedział: „byłem przybyszem, a przyjęliście mnie" (Mt 25, 35). W migracjach odkrywają następnie Boży plan zbawienia; a wzajemne zbliżanie się ludzi do siebie przypomina zebranie przed Wieczernikiem w dniu Zesłania Ducha Świętego ${ }^{48}$. Wobec różnych zagrożeń i przeszkód, z jakimi spotykają się migranci, wspólnota kościelna zajmuje stanowisko solidarności i pomocy. W nauczaniu kościelnym wskazuje się na przyczyny, w tym nierówności społeczne i ekonomiczne, popychające ludzi do opuszczenia swych stron rodzinnych; często są to formy nielegalnej migracji, podczas której osoby stają się przedmiotem wyzysku i przestępstw. Magisterium Kościoła formułuje potrzebę stworzenia zabezpieczeń prawnych, które będą przeciwdziałać wszelkiej dyskryminacji względem migrujących ${ }^{49}$. Myśl kościelna wskazuje na szereg postulatów moralnych związanych z migracją, takich jak np.: uznanie prymatu osoby ludzkiej w społeczeństwie, respektowanie zasady równości społecznej, zaprzestanie

\footnotetext{
${ }^{46}$ Por. Franciscus, Litterae apostolicae motu proprio Humanam progressionem, 17.08.2016, http://w2.vatican.va/content/francesco/la/motu_proprio/documents/ papa-francesco-motu-proprio_20160817_humanam-progressionem.html [dostęp 7.09.2017]. Wskazany dokument zmienia jednocześnie normy konstytucji Pastor bonus: nr 142-153.

${ }^{47}$ Por. Erga migrantes caritas Christi, nr 3; A. Gimenez Reception, The Global World and its New Challenges: Urbanization, Migration and Postmodernity, w: Il Cammino della missione. Convegno Internazionale a cinquant'anni dalla promulgazione del Decreto Conciliare Ad Gentes, red. A. Trevisiol, Roma 2015, s. 495-496. 498-502.

${ }^{48}$ Por. Erga migrantes caritas Christi, nr 12.

${ }^{49}$ Por. tamże, nr 30.
} 
handlu ludźmi i traktowania cudzoziemców jak niewolników, troska o właściwe prawodawstwo, integracja społeczna migrantów ${ }^{50}$.

W aktualnej sytuacji, Kościół niezmiennie widzi swoje zadanie ewangelizacji, aby dzielić się wiarą. Nie tylko z wędrującymi chrześcijanami, ale także $\mathrm{z}$ wyznawcami innych religii i niewierzącymi ${ }^{51}$. Przed publikacją instrukcji Erga migrantes caritas Christi, papież Jan Paweł II wskazywał na zadanie ewangelizacji w encyklice Redemptoris missio, wobec masowych migracji, przemieszczania się uchodźców, ale też dechrystianizacji niektórych krajów ${ }^{52}$.

Migranci wędrują do Europy, pochodząc z różnych krajów i kontynentów. Migrują chrześcijanie i niechrześcijanie. Wielu spośród tych, którzy docierają do Europy jest muzułmanami. Ostatnie lata przyniosły na tym kontynencie liczne zamachy terrorystyczne, dokonane przez wyznawców islamu, w nawiązaniu do idei wojny religijnej: dżihadu. Znaczne środowiska islamskie w takich krajach jak: Wielka Brytania, Francja, Niemcy, Holandia i Belgia tworzą zaplecze dla zagrożenia terrorystycznego. Polska jest $\mathrm{w}$ innej sytuacji. Z badań takich, jak Narodowy Spis Powszechny Polski z 2011 r., wynika, że liczba wyznawców innych religii (niechrześcijańskich) jest stosunkowo niewielka, tak jak i tych, którzy deklarują sceptycyzm religijny, czy postawy areligijności ${ }^{53}$. Jest to co prawda częściowa informacja, deklarowanie przynależności religijnej jest w takim przypadku

\footnotetext{
${ }^{50}$ Por. R. Urbańczy , Z. Skwierczyński, Migracja-aspekt teologiczny, kol. 961-962; P.A. Bonnet, Comunione ecclesiale, migranti e diritti fondamentali, w: Pontificio Consiglio della Pastorale Per i Migranti e gli Itineranti, Migrazioni e diritto ecclesiale. La pastorale della mobilità umana nel nuovo Codice di diritto canonico, Padova 1992, s. 23-54.

${ }^{51}$ Por. Erga migrantes caritas Christi, nr 9.

${ }^{52}$ Por. Jan PaweŁ II, Redemptoris missio, nr 32. 37; A. Domaszk, Nowe horyzonty misji „Ad gentes”, s. 30-34; TENŻE, Misja ad gentes $w$ Polsce?, w: Fides, quae de verbo nascitur et nutritur. Nauczycielskie zadanie Kościoła wobec 1050. rocznicy Chrztu Polski, red. J. Krajczyński, A. Domaszk, Płock 2016, s. 204-208.

${ }^{53}$ Por. GŁówny Urząd Statystyczny, Struktura narodowo-etniczna, językowa i wyznaniowa ludności Polski. Narodowy Spis Powszechny Ludności i Mieszkań 2011, [dostęp 23.08.2016], s. 97.
} 
fakultatywne. Ze względu na niewielki poziom migracji, liczba wyznawców islamu w Polsce nadal jest minimalna.

Odniesienia do migrantów, niezależnie od wyznawanej przez nich religii, powinny być nacechowane szacunkiem należnym każdemu człowiekowi, w którym działa moc Ducha Świętego ${ }^{54}$. Niemniej konieczne jest zastosowanie roztropności w przyjmowaniu i gościnności, w stosowaniu kultury otwartości, oraz integracji wraz z uznaniem podstawowych praw imigrantów ${ }^{55}$. Aktualna sytuacja również prowadzi Kościół do wypracowania odpowiednich metod opieki duszpasterskiej nad imigrantami i uchodźcami, z których część stanowią katolicy oraz wyznawcy innych społeczności chrześcijańskich, a część niechrześcijanie ${ }^{56}$. Tak jak na początku swojej historii, Kościół przyjmuje otwartą postawę: „,otwiera szeroko swe drzwi i staje się domem, do którego wszyscy mogą wejść i czuć się u siebie, zachowując własną kulturę i własne tradycje, byleby nie sprzeciwiały się one Ewangelii" ${ }^{27}$.

Zachowując otwartość, jak i dostrzegając zmiany, jakie imigracja przynosi ze sobą do Europy, należy podjąć refleksję nad tym, że sytuacja ta stanowi wyzwanie dla Kościoła, dla jego nowych horyzontów misyjnych. W tym znaczeniu należy ponownie odczytać ewangelizacyjny wymiar encykliki Redemptoris missio: Jan Paweł II wskazał na migrację osób, jako okazję do kontaktów i wymiany kulturalnej, do dialogu i braterstwa; które Kościół winien wciągnąć w krąg swej troski apostolskiej ${ }^{58}$. Oprócz powszechnego wymiaru, zagadnienie dotyczy również poszczególnych Kościołów partykularnych, które nie mogą być w pełni wiarygodne i misyjne w innych krajach oraz kontynentach, ,jeśli nie zatroszczą się poważnie o niechrześcijan we własnym domu" 59 .

\footnotetext{
${ }^{54}$ Por. Jan PaweŁ II, Redemptoris missio, nr 29.

${ }^{55}$ Por. Tenże, Ecclesia in Europa, nr 100-102; Erga migrantes caritas Christi, nr 60.

${ }^{56}$ Por. Jan PaweŁ II, Ecclesia in Europa, nr 103.

${ }^{57}$ Tenże, Redemptoris missio, nr 24.

${ }^{58}$ Por. tamże, nr 37. Przegląd dokumentów Kościoła, por. V. DE PAOLIS, La cura pastorale dei migranti nella Chiesa. Una rassegna dei principali documenti, Quaderni di Diritto Ecclesiale 21(2008)1, s. 11-28.

${ }^{59}$ Jan PaweŁ II, Redemptoris missio, nr 34.
} 


\subsection{Wybrane normy prawa kanonicznego}

\subsubsection{Biskupi Kościoła}

Wszyscy wierni, zgodnie z treścią kan. 781 Kodeksu z 1983 r., ponoszą współodpowiedzialność za misje ${ }^{60}$, poczynając od Biskupa Rzymskiego i Kolegium Biskupów, przez Kongregację Ewangelizacji Narodów (inaczej Kongregację Rozkrzewiania Wiary) ${ }^{61}$. Następnie dotyczy to każdego biskupa, nie tylko w tzw. krajach misyjnych ${ }^{62}$, ale również w poszczególnym Kościele partykularnym ma on obowiązek szczególnej troski o dzieło misyjne ${ }^{63}$. Z tego płynie wniosek, że w każdej diecezji, również w Polsce, ${ }^{64}$ należy podejmować aktywność misyjną, w zakresie animacji i konkretnych projektów misyjnych. Zgodnie ze wskazaniami kodeksowymi, podstawowe działania biskupa obejmują: popieranie powołań misyjnych; wyznaczenie kapłana/struktur dla popierania poczynań misyjnych, w tym Papieskich Dzieł Misyjnych; organizowanie dnia misyjnego; pomoc materialną ${ }^{65}$. W ten sposób biskup diecezjalny wpływa na świadomość aktualności zagadnienia, pobudza, promuje i kieruje inicjatywami misyjnymi ${ }^{66}$. Obowiązkiem pasterzy jest troska o wszystkich wiernych powierzonych jego pieczy, ale także o nieochrzczonych, ażeby i im zajaśniała prawda i miłość Chrystusa ${ }^{67}$.

Popieranie powołań misyjnych obejmuje m.in. alumnów seminarium duchownego, aby formować ich do ducha misyjnego, do

\footnotetext{
${ }^{60}$ Por. A. Domaszk, Misja ad gentes w Polsce?, s. 195-204.

${ }^{61}$ Por. KPK 1983, kan. $782 \$ 1$, Ad gentes, nr 29; JoAnnes Paulus II, Pastor Bonus, nr 85-92; Tenże, Redemptoris missio, nr 63; TenżE, Posynodalna adhortacja apostolska Pastores gregis, 16.10.2003, Kraków 2003, nr 65.

${ }^{62}$ Por. F. JАвŁoński, Terytoria misyjne $w$ świetle Kongregacji Ewangelizowania Narodów w 390. rocznicę jej powstania (1622-2012), Warszawa 2012.

${ }^{63}$ Por. KPK 1983, kan. $782 \$ 2$.

${ }^{64}$ Por. F. JaвŁoński, Recepcja idei misyjnej w Polsce po Soborze Watykańskim II, Kraków 2003.

${ }^{65}$ Por. KPK 1983, kan. 791, kan. $790 \$ 1-2$.

${ }^{66}$ Por. Ad gentes, nr 30; Jan Pawe乇 II, Pastores gregis, nr 65.

${ }^{67}$ Por. KPK 1983, kan. $383 \$ 1.4$.
} 
ewentualnej pracy misyjnej, nie tylko w Kościele partykularnym, z którego się wywodzą ${ }^{68}$. Jednym $\mathrm{z}$ istotnych zakresów animacji misyjnej jest działalność Papieskich Dzieł Misyjnych: Dzieło Rozkrzewiania Wiary, Dzieło św. Piotra Apostoła, Dzieło Dziecięctwa Misyjnego, Papieska Unia Misyjna Duchowieństwa ${ }^{69}$. Ważnym wydarzeniem powinien być Światowy Dzień Misyjny (tydzień misyjny).

Działalność misyjną zakreślają także wskazania Konferencji Episkopatu, dotyczące otwartości na osoby przybywające z innych krajów, $\mathrm{z}$ racji pracy lub odbycia studiów ${ }^{70}$. W Polsce wspólnym dziełem Konferencji Episkopatu jest Centrum Formacji Misyjnej, które przygotowuje misjonarzy do ich przyszłej pracy, jak i wspiera misjonarzy przyjeżdżających do Polski ${ }^{71}$. Warto zauważyć powstałe w Warszawie: Werbistowskie Centrum Migranta Fu Scherfü ${ }^{72}$. Wydaje się, że należy postulować powstawanie kolejnych struktur kościelnych w Polsce, otwartych na migrujących chrześcijan i niechrześcijan.

\subsubsection{Misjonarze}

Posługę misyjną pełnią zwłaszcza misjonarze. Wydaje się, że należy tradycyjne rozumienie tej instytucji kanonistycznej zastosować w relacji do migrantów. W prawie powszechnym Kościoła w osobie misjonarza odnajdą się: świeccy, duchowni, osoby konsekrowane,

${ }^{68}$ Por. tamże, kan. $256 \$ 2$, kan. $257 \$ 1$; D. Martínez Martínez, La solicitud por la Iglesia en la formación de los candidatos al presbiterado, a la luz del canon 257 $\$ 1$ del Código de Derecho Canónico de 1983 (praca doktorska, archiwum UKSW), Warszawa 2005.

${ }^{69}$ Por. Pastor Bonus, nr 91. Por. witrynę Papieskich Dzieł: http://missio.org.pl/ pontyfikat/ [dostęp 25.10.2017].

${ }^{70}$ Por. KPK 1983, kan. 792; Ad gentes, nr 31; Jan PAwe乇 II, Redemptoris missio, $\mathrm{nr} 64$.

${ }^{71}$ Por. http://www.cmf1.home.pl/cfm/ [dostęp 25.10.2017]. Również inne instytuty zakonne czy stowarzyszenia życia apostolskiego prowadzą własne ośrodki misyjne w Polsce, które przygotowują do misji, otaczają opieką misjonarzy, wracających na urlopy lub potrzebujących pomocy medycznej, przygotowują do wolontariatu misyjnego, jak: Salezjański Ośrodek Misyjny w Warszawie.

${ }^{72}$ Por. J. Gniadek, Centrum Migranta i ludzie w drodze, Biuletyn Tygodniowy Centrum Informacyjnego Zakonów 44(2017)453, s. 8-10. 
czy gdy pochodzą z terenów misyjnych, czy zamieszkują kraje, dokąd migrują ludzie ${ }^{73}$. Ważnym elementem jest posłanie, dokonane przez władzę kościelną: otrzymanie misji (missio), również w kontekście europejskim. Znaczącą grupą pośród misjonarzy są kapłani, reprezentujący Chrystusa i uczestniczący w potrójnej misji Kościoła ${ }^{74}$.

Prawo kanoniczne zobowiązuje duszpasterzy, zwłaszcza biskupów i proboszczów, do troski, aby głosić słowo Boże również tym, którzy ze względu na warunki życia nie mogą korzystać z ogólnej i zwyczajnej opieki pasterskiej albo są jej pozbawieni; ewangelizacja dotyczy również niewierzących, którzy mieszkają na danym terytorium ${ }^{75}$. Posługa duszpasterska nie może ogarniać jedynie tych, którzy już przynależą do wspólnot parafialnych; więc należy głosić słowo Boże także imigrantom.

Pośród misjonarzy należy następnie wskazać osoby konsekrowane. Z racji ich konsekracji i poświęcenia się na służbę Kościołowi, powinni oni angażować się w działalność misyjną ${ }^{76}$. Powołanie misyjne istotowo łączy się z posłannictwem osób konsekrowanych ${ }^{77}$. Ich konsekracja koreluje z dyspozycyjnością, przedsiębiorczością, pomysłowością i wielkodusznością w służbie Kościoła, nawet z narażeniem zdrowia i życia ${ }^{78}$. Konkretna posługa misyjna wyraża się na wiele sposobów, w wymiarze duchowym, czy aktywności

\footnotetext{
${ }^{73}$ Por. KPK 1983, kan. 784; Ad gentes, nr 23-27.

${ }^{74}$ Por. tamże, nr 39; Jan PAwe II, Redemptoris missio, nr 67-68.

${ }^{75}$ KPK 1983, kan. $771 \$ 1-2$, kan. $528 \$ 1$. Por. M. GIDA, La referencialidad ministerial del párroco en su misión de servico en el anuncio del Evangelo en la parroquia. Parte primera, Periodica 99(2010)1, s. 73-93; tenże, La referencialidad ministerial del párroco... Parte segunda, Periodica 99(2010)2, s. 201-249.

${ }^{76}$ Por. KPK 1983, kan. 783.

${ }_{77}$ Por. Jan PAweŁ II, Posynodalna adhortacja apostolska Vita consecrata, 25.03.1996, Ząbki 1996, nr 72, 77-78; E. GAmBARI, Życie zakonne po Soborze Watykańskim II, tłum. z włos. J.E. Bielecki, Kraków 1998, s. 522-524.

${ }^{78}$ Por. PAulus VI, Adhortatio apostolica Evangelii nuntiandi, 08.12.1975, AAS 68 (1976), s. 5-76, nr 69.
} 
zewnętrznej; w charyzmacie instytutów życia kontemplacyjnego, jak i życia czynnego ${ }^{79}$.

Misjonarzami są także liczne osoby świeckie. Na ich możliwości oddziaływania wskazywał soborowy dekret Ad gentes ${ }^{80}$. Na mocy chrztu św., współuczestniczą w potrójnym urzędzie Chrystusa, pełnią różne posługi i funkcje, w strukturach parafialnych i diecezjalnych, w ruchach kościelnych i stowarzyszeniach ${ }^{81}$. Wskazać też można: animację modlitwy, prowadzenie śpiewu i liturgii, przewodniczenie wspólnotom podstawowym i grupom biblijnym, dziełom miłosierdzia, administrację dobrami doczesnymi, kierowanie grupami apostolskimi, nauczanie religii w szkołach, czy jakiekolwiek inne zaangażowanie czasu, umiejętności lub środków ${ }^{82}$.

\subsubsection{Jak ewangelizować?}

Stawiając tezę o potrzebie ewangelizacji skierowanej na migrantów, rodzi się pytanie, jak ewangelizować we współczesnej Europie? Zanim pasterze wypracują nowe formy, warto sięgać do sprawdzonych rozwiązań prawa kanonicznego. Nie jest już celem, jak na terenach misyjnych, budowanie nowych Kościołów partykularnych w Europie, gdyż one już istnieją ${ }^{83}$.

Niezmiennym celem pozostaje jednak budzenie wiary poprzez świadectwo: misjonarzy, poszczególnych katolików, rodzin i wspólnot chrześcijańskich. Świadectwo jest zasadniczą i pierwszą formą ewangelizacji ${ }^{84}$. Przykład wiary oraz wierność wartościom z niej wypływającym jest najskuteczniejszym narzędziem misyjnym. Warto powtórzyć słynne słowa papieskie: „Człowiek współczesny bardziej

\footnotetext{
${ }^{79}$ Por. Ad gentes, nr 18, 40; JAN PAweŁ II, Redemptoris missio, nr 65-66. 69-70; Erga migrantes caritas Christi, nr 80-85.

${ }^{80}$ Por. Ad gentes, nr 41.

${ }^{81}$ Por. Jan Pawe乇 II, Redemptoris missio, nr 71-73; Erga migrantes caritas Christi, nr 86-88. Na tzw. terenach misyjnych, świeccy pełnią rolę katechistów, por. KPK 1983, kan. $785 \$ 1$.

${ }^{82}$ Por. Jan PaweŁ II, Redemptoris missio, nr 74.

${ }^{83}$ Por. KPK 1983, kan. 786.

${ }^{84}$ Por. Ad gentes, nr 11-12; Jan PaWeŁ II, Redemptoris missio, nr 42-43.
} 
wierzy świadkom, aniżeli nauczycielom, bardziej doświadczeniu, aniżeli doktrynie, bardziej życiu i faktom, aniżeli teoriom" 85 . Uobecnianie w świecie samego Chrystusa przez osobiste świadectwo bardziej przemawia, niż same tylko zewnętrzne dzieła czy projekty, np. charytatywne lub społeczne, również, gdy są kierowane do migrantów ${ }^{86}$.

Kościół od początku swej posługi ewangelizacyjnej, adaptował formy przekazu do lokalnej kultury. Ze względu na kontekst miejsca i osób, uwzględniał wymagania inkulturacji. Dlatego misjonarze przez świadectwo życia i słowa mają nawiązać dialog z niewierzącymi w Chrystusa; tak, aby w sposób przystosowany do ich mentalności i kultury, przekazywać im orędzie ewangeliczne ${ }^{87}$. Tę tradycyjną metodę dialogu i adaptacji również należy zastosować w kontekście migracji, wobec osób napływających do Europy. W procesie inkulturacji trzeba włączać Ewangelię i myśl Kościoła w kultury migrantów; przekazując istotę chrześcijaństwa w sposób dla nich zrozumiały oraz przyjmując od nich te pozytywne wartości kulturowe, które nowi mieszkańcy przynoszą ze sobą ${ }^{88}$. W ramach inkulturacji przejmuje się, uzdrawia i przekształca bogactwo poszczególnych kultur, tak, aby było ono zgodne z zasadami Ewangelii. Nie należy jedynie odrzucać czy marginalizować migrantów; przeciwnie współcześni misjonarze winni wsłuchiwać się w ludzi inaczej myślących i odkrywać wartości ich kultury. Niezbędne są tu szacunek, miłość i pokora, na wzór Chrystusa $^{89}$. Jednym z podstawowych elementów każdej kultury jest język. Można oczekiwać, że migranci z czasem - niekiedy bardzo długim - poznają język kraju, gdzie mieszkają. Jednak od misjonarzy oczekuje się bardziej dynamicznej postawy, tj. że będą uczyli się języka ludzi, do których chcą dotrzeć z orędziem Ewangelii, również na gruncie europejskim ${ }^{90}$.

\footnotetext{
${ }^{85}$ Tamże, nr 42; por. Paulus VI, Evangelii nuntiandi, nr 41.

${ }^{86}$ Por. Jan Pawe II, Vita consecrata, nr 72, 76.

${ }^{87}$ Por. KPK 1983, kan. $787 \$ 1$.

${ }^{88}$ Por. Jan PaweŁ II, Redemptoris missio, nr 52-54; Paulus VI, Evangelii nuntiandi, nr 20; por. także J. RóżAńsKi, Wokół koncepcji inkulturacji, Warszawa 2008.

${ }^{89}$ Por. Jan PaweŁ II, Vita consecrata, nr 79-80.

${ }^{90}$ Por. Tenże, Redemptoris missio, nr 53.
} 
Wiara jest wolnym wyborem sumienia każdego człowieka. Dlatego Kościół proponuje przyjęcie wiary katolickiej w duchu wolności, co oznacza, że we wszelkich poczynaniach misyjnych należy uwzględniać wymóg wolności religijnej. Dopiero, kiedy osoba odpowiednio pouczona i przygotowana do przyjęcia orędzia ewangelicznego, poprosi w sposób wolny, może być dopuszczona do przyjęcia chrztu ${ }^{91}$. Kościół sprzeciwia się jakiemukolwiek zmuszaniu kogokolwiek do przyjęcia wiary katolickiej, czy nakłaniania do tego w niegodziwy sposób $^{92}$. Z drugiej strony również nie można nikogo odwodzić od wiary w sposób wymuszony czy niesprawiedliwy, czego niestety w wielu krajach świata dopuszczają się przedstawiciele niektórych religii, prześladując chrześcijan.

Respektując zasadę wolności religijnej, wspólnota kościelna jest jednakże świadoma tego, że ma obowiązek głoszenia Ewangelii i tajemnicy Chrystusa. Gdyż każdy człowiek „ma prawo usłyszeć Dobrą Nowinę Boga, który objawia się i daje siebie w Chrystusie"93. W odniesieniu do migrantów - niechrześcijan, katolicy nie mogą przemilczać swojej wiary. Zwracał na to uwagę Jan Paweł II: „Dziś wezwanie do nawrócenia, kierowane przez misjonarzy do niechrześcijan, poddaje się pod dyskusję lub przemilcza. Widzi się w nim akt 'prozelityzmu'; mówi się, że wystarczy pomagać ludziom, by byli bardziej ludźmi i bardziej wierni własnej religii, że wystarczy budować wspólnoty ludzkie zdolne do działania na rzecz sprawiedliwości, wolności, pokoju, solidarności" 94 .

Odważne głoszenie Ewangelii imigrantom w Europie, o ile zostanie przyjęte, może prowadzić do przyjęcia chrztu i włączenia osób we wspólnotę Kościoła katolickiego. Wspólnota katolicka niezmiennie głosi potrzebę nawrócenia, która prowadzi do przyjęcia chrztu, jako sakramentu zbawienia ${ }^{95}$. Sprawdzoną od wieków pozostaje instytucja

\footnotetext{
${ }^{91}$ Por. KPK 1983, kan. $787 \$ 2$.

${ }^{92}$ Por. Ad gentes, nr 13.

${ }^{93}$ Jan Pawe II, Redemptoris missio, nr 46.

${ }^{94}$ Tamże.

${ }^{95}$ Por. tamże, nr 46-47; KPK 1989, kan. 849.
} 
katechumenatu, oferowana również migrantom; w trakcie tego okresu osoba stopniowo jest włączana w życie i tajemnicę Kościoła. Występują dwa zasadnicze etapy: wstępny katechumenat lub inaczej prekatechumenat oraz właściwy katechumenat ${ }^{96}$. Osoby, które wyraziły wolę przyjęcia wiary w Chrystusa, po odbyciu prekatechumenatu, powinni być dopuszczeni do katechumenatu z zastosowaniem obrzędów liturgicznych ${ }^{97}$. Celami tego okresu wtajemniczenia są: nauka i praktyka życia chrześcijańskiego, wprowadzenie w tajemnicę zbawienia oraz w życie przepojone wiarą, a także w liturgię, umiłowanie Ludu Bożego i apostolstwa ${ }^{98}$. Szczegółowe normy na temat katechumenatu ustanawia Konferencja Episkopatu ${ }^{99}$. A po udzieleniu sakramentu chrztu dokonuje się dalsza formacja neofitów, aby pełniej poznali prawdę Ewangelii i nauczyli się właściwego wypełniania obowiązków chrześcijanina, nabierali szczerej miłości do Chrystusa i Kościoła ${ }^{100}$. Więcej wytycznych na temat przygotowania do chrztu dorosłych i instytucji katechumenatu podają poszczególne Kościoły partykularne ${ }^{101}$.

Pytanie o to, jak ewangelizować prowadzi następnie do dialogu międzyreligijnego, co jest podejmowane w wielu dokumentach kościelnych. Dialog taki nie przeciwstawia się misji ad gentes. Kościół głosi niezmiennie, że zbawienie pochodzi od Jezusa Chrystusa. Myśl

\footnotetext{
${ }^{96}$ Por. Obrzędy chrześcijańskiego wtajemniczenia dorosłych, Katowice 1988; G. TREVISAN, Il catecumenato, istruzione e tirocinio della vita cristiana, Quaderni di Diritto Ecclesiale 27(2014)3, s. 263-281; A. MigliavaccA, Il catecumenato e la prassi ecclesiale, tamże, s. 282-313; P. MĄKOSA, Preewangelizacja pierwszym i koniecznym etapem formacji chrześcijańskiej, Katecheta 54(2010)7-8, s. 25-34.

${ }^{97}$ Por. KPK 1983, kan. $788 \$ 1$.

${ }^{98}$ Por. tamże, kan. $788 \$ 2$.

${ }^{99}$ Por. tamże, kan. $788 § 3$.

${ }^{100}$ Por. tamże, kan. 789.

${ }^{101}$ Por. Z. JANCZEwsKi, Recepcja Kodeksu prawa kanonicznego z 1983 r.w zakresie prawa o sakramentach w prawodawstwie Konferencji Episkopatu Polski i II Polskiego Synodu Plenarnego (chrzest, bierzmowanie Eucharystia, pokuta, namaszczenie chorych, święcenia), w: 30 lat od promulgacji Kodeksu Prawa Kanonicznego. Doświadczenia Kościoła katolickiego w Polsce, red. A. Domaszk, Warszawa 2014, s. 98-101; A. Domaszk, Możliwości zastosowania Internetu w misji Kościoła. Studium kanoniczno-teologiczne, Kraków 2013, s. 238-244.
} 
o inkulturacji, więc i dostrzeganiu elementów prawdy i pobożności w innych tradycjach religijnych, nie przekreśla i nie zmniejsza obowiązku głoszenia Ewangelii Jezusa - w ramach rzeczonego dialogu oraz wzywania do przyjęcia wiary chrześcijańskiej i chrztu ${ }^{102}$.

Wierność wierze katolickiej, pełna szacunku dla innych, nie może jednakże relatywizować własnych przekonań, czy stwarzać wrażenia, jakby wszystkie religie miały taką samą wartość; dialog międzyreligijny prowadzi do spotkania z Jezusem i Kościołem, który jest konieczny do zbawienia ${ }^{103}$. W rzeczonym dialogu, w imię tzw. poprawności politycznej, relatywizmu religijnego lub z innych powodów, nie można jedynie podkreślać praw migrantów i ukazywać ich trudną sytuację, kosztem zaprzepaszczenia przesłania misyjnego i ukazywania zbawienia w Jezusie.

W ewangelizacji należy zadbać o przepływ informacji. Wspólnota kościelna, głosząc Ewangelię, powinna zadbać o przystępność informacji dla imigrantów. Ci, którzy chcą poznać Kościół i chrześcijaństwo, mogą szukać informacji u osób, które już znają. Mogą zwrócić się do parafii, na terenie której przebywają. Wskazane jest

\footnotetext{
${ }^{102}$ Por. Jan PaweŁ II, Redemptoris missio, nr 55-57; por. także Ad gentes, nr 11; Concilium Vaticanum II, Declaratio Nostra aetate, 28.10.1965, AAS 58(1966), s. 740-744; PAulus VI, Litterae encyclicae Ecclesiam suam, 06.08.1964, AAS 56(1964), s. 609-659; Tenże, Evangelii nuntiandi, nr 53; SeCretariatus Pro nON ChristiaNIs, L'atteggiamento della Chiesa di fronte al seguaci di altre religioni (Riflessioni e orientamenti su dialogo e missione), 04.09.1984, AAS 76(1984), s. 816-828; PonTIFIcio Consilio pro Dialogo inter Religiones, Congregatione pro Gentium Evangelizatione, Instructio Dialogo e Annuncio, 19.05.1991, AAS 84(1992), s. 414-446; Jan PaWeŁ II, Vita consecrata, nr 102; Tenże, Ecclesia in Europa, nr 55; Erga migrantes caritas Christi, nr 69; W. KLUJ, Dialog międzyreligijny a przepowiadanie Jezusa Chrystusa - dwa podstawowe dokumenty i dwa wydarzenia, w: Misje i religie. Księga pamiątkowa poświęcona ks. prof. dr. hab. Władysławowi Kowalakowi z okazji 45-lecia działalności misjologii w ATK i UKSW w Warszawie, red. J. Różański, Górna Grupa 2014, s. 109-124; P.C. PHAN, Dialogo interreligioso, w: Migrazioni. Dizionario socio-pastorale, red. G. Battistella, Milano 2010, s. 365-371.

${ }^{103}$ Por. Jan PaweŁ II, Pastores gregis, nr 68; Congregatio Pro Doctrina Fidei, Declaratio Dominus Iesus, 06.08.2000, AAS 92(2000), s. 742-765, nr 22; Erga migrantes caritas Christi, nr 59; Jan PAWEe II, Ecclesia in Europa, nr 55.
} 
także, aby informacja była dostępna w łatwy sposób. Chodzi o zbudowanie modułów językowych, np. angielskojęzycznych na portalach diecezjalnych, czy także w innych językach, typowych dla migrantów w określonym kraju. Nie są to tylko zapytania o pomoc charytatywną, ale również o chrześcijaństwo, katechumenat dla dorosłych, kontakt z osobami, z którymi można się spotkać i rozmawiać na tematy wiary.

\subsection{Migranci niechrześcijanie w optyce Erga migrantes caritas Christi}

Wiele szczegółowych wskazań w odniesieniu do migrantów wnosi treść instrukcji Erga migrantes caritas Christi. Pomijając w tym opracowaniu te, które dotyczą duszpasterstwa skierowanego do katolików, warto wydobyć niektóre odnoszące się do niekatolików ${ }^{104}$.

Jedną z zasad jest potrzeba uszanowania własnych miejsc kultu (kościoły, kaplice), że są one zastrzeżone dla katolickich czynności ewangelizacyjnych i duszpasterskich ${ }^{105}$. Tym samym nie powinny być udostępniane wyznawcom niechrześcijańskich religii, czy na cele świeckie ${ }^{106}$. Dla celów charytatywnych lub w celu integracji imigrantów, można otworzyć inne pomieszczenia kościelne, zwykle przeznaczone na cele socjalne. Jednoczenie osób podejmowane w takich przestrzeniach wspiera ich integrację, przezwycięża kulturowe i religijne granice oraz umacnia wzajemne kontakty.

Innym miejscem spotkania jest szkoła. Dotyczy to także szkół katolickich, które są zobowiązane do zachowania swej tożsamości, co obejmuje również chrześcijańską koncepcję wychowania ${ }^{107}$. Jednakże nie wyklucza to przyjmowania dzieci migrantów do takiej szkoły. Tym niemniej rodzice, podczas rekrutacji dzieci do szkoły katolickiej, mają być poinformowani o określonym, wyznaniowym charakterze szkoły. Pamiętając o wymogach wolności religijnej, nie można zobowiązywać dzieci - przynależących do innych religii - do udziału w katolickiej liturgii, katechezie, czy innych tego typu wydarzeniach, jak również

\footnotetext{
104 Por. A. Domaszk, Misja ad gentes w Polsce?, s. 217-219.

${ }^{105}$ Por. KPK 1983, kan. 1205-1243.

${ }^{106}$ Por. Erga migrantes caritas Christi, nr 61.

107 Por. KPK 1983, kan. 803.
} 
narzucać sposobów żywienia sprzecznych z religią rodziców ${ }^{108}$. Czym innym jest otwartość propozycji (fakultatywność) i zaproszenie dzieci do udziału w lekcjach religii katolickiej, kierowane również do wyznawców innych religii, czy do aktywności całych rodzin w życiu szkolnym i wydarzeniach pozalekcyjnych. Takie założenia budują przestrzeń poznania chrześcijaństwa i uczą wzajemnego szacunku.

Wraz ze zwiększającą się różnorodnością społeczeństw europejskich dochodzi do częstszego zawierania małżeństw: osób pochodzących $\mathrm{z}$ różnych religii. Kościół sprzyja przede wszystkim małżeństwom obojga katolików. Jeśli jednak narzeczeni, w sposób świadomy i dobrowolny, proszą o ślub, a jedno z nich wyznaje inną religię, stosuje się dyspensę ${ }^{109}$. Jednak biorąc pod uwagę to, by nie utracić wiary katolickiej oraz wychować dzieci w tej wierze, Kościół odradza związki katolików z niechrześcijanami ${ }^{110}$.

Dotyczy to również małżeństw katolików z muzułmanami (coraz liczniejsi w Europie). Chodzi tu także o przeprowadzenie wcześniejszego przygotowania, aby narzeczeni (zwłaszcza kobieta) zostali doprowadzeni do poznania głębokich różnic kulturowych i religijnych oraz mieli świadomość problemów, jakim trzeba stawić czoła pomiędzy nupturientami, w odniesieniu do ich rodzin oraz środowiska pochodzenia strony muzułmańskiej, do którego ewentualnie powrócą. Jeśli oboje zdecydują się na zawarcie małżeństwa w konsulacie kraju islamskiego, strona katolicka powinna uważać, by przy tej okazji nie

\footnotetext{
${ }^{108}$ Por. Erga migrantes caritas Christi, nr 62; JAN PAweŁ II, Ecclesia in Europa, nr 59; TenżE, Pastores gregis, nr 52; J. Hendriks, Migrazione e scuole cattoliche, w: Pontificio Consiglio della Pastorale per i Migranti e gli Itineranti, Migrazioni e diritto ecclesiale. La pastorale della mobilità umana nel nuovo Codice di diritto canonico, Padova 1992, s. 169-176.

${ }^{109}$ Por. KPK 1983, kan. 1086. 1125-1126.

${ }^{110}$ Por. Erga migrantes caritas Christi, nr 63; J. PRUDER, Il diritto matrimoniale islamico e il problema del matrimonio fra donna cattolica e musulmano, w: PonTIficio Consiglio della Pastorale Per i Migranti e gli Itineranti, Migrazioni e diritto ecclesiale. La pastorale della mobilità umana nel nuovo Codice di diritto canonico, Padova 1992, s. 133-168; G. DzIerżon, Małżeństwo katolików z muzułmanami, w: Małżeństwo i rodzina w prawie kanonicznym i w prawie polskim, red. J. Krukowski, M. Sitarz, J. Gręźlikowski, Lublin 2017, s. 125-140.
} 
wyznać zarazem schachada (wyznanie muzułmańskiej wiary), bądź też nie podpisywać dokumentu, który go zawiera, co może wynikać z nieświadomości czy nieznajomości języka ${ }^{111}$. Tak zawierane związki cywilne wymagają na forum kanonicznym dyspensy oraz wsparcia ze strony wspólnoty katolickiej. Zwłaszcza w odniesieniu do kobiety, która jest mniej chroniona w muzułmańskiej tradycji kulturowej.

W małżeństwie osób należących do różnych religii jedną z ważniejszych spraw jest wychowanie, również w przestrzeni wyznaniowej. Na etapie przygotowania do zawarcia związku należy tę sprawę oraz przyszły chrzest dzieci omówić z narzeczonymi, tak by strona katolicka wiedziała o stanowisku Kościoła i zobowiązała się do tego, czego wymaga wspólnota kościelna. Może się też zdarzyć, że dorosły muzułmanin pragnie dokonać konwersji i poprosi o chrzest, co wymaga szczególnej uwagi. Tak z racji natury muzułmańskiej religii, zabraniającej porzucenia islamu, jak też ze względu na negatywne konsekwencje (sankcje karne dla osoby konwertującej), które z takiego wydarzenia wynikają ${ }^{112}$. Osoba porzucająca islam jest odrzucana i prześladowana przez swoje środowisko i rodzinę. Bardzo często, zwłaszcza w krajach, gdzie ta religia dominuje, grożą jej sankcje wynikające m.in. z prawa państwowego, jak i śmierć z rąk najbliższych krewnych ${ }^{113}$.

Postawa wspólnoty katolickiej skierowana ku imigrantom zasadniczo jest otwarta. Jednocześnie zakłada się dowartościowanie zasady wzajemności. Chodzi o budowanie takich relacji, które opierają się na wzajemnym poszanowaniu i sprawiedliwości w sprawach prawno-religijnych. Szanując wybory religijne imigrantów, Kościół wyraża jednocześnie oczekiwanie i domaga się obrony praw mniejszości tam, gdzie niechrześcijańskie wspólnoty religijne są większością.

\footnotetext{
${ }^{111}$ Por. Erga migrantes caritas Christi, nr 67.

112 Tamże, nr 68.

${ }^{113}$ Por. J. FAdelle, Le prix a payer, Éditions de l'CEuvre 2011; wyd. pol.: TEnże, Bez względu na cenę, Poznań 2012; Le livre noire de la condition des chrêtiens dans le monde, red. J.M. Falco, T. RADELIFFe, A. RiCCARDI, XO Editions 2014; wyd. pol.: Czarna księga prześladowań chrześcijan w świecie, Poznań 2015.
} 
Należy tu wskazać na licznych migrantów chrześcijańskich w krajach o większości ludności niechrześcijańskiej: poza Europą, gdzie prawo do wolności religijnej jest mocno ograniczane albo naruszane ${ }^{114}$.

W dialogu międzyreligijnym myśl katolicka przyjmuje postawę ewangeliczną. Co oznacza - wobec wzrastającej liczby imigrantów muzułmańskich - potrzebę oczyszczania pamięci dotyczącej przeszłości z nieporozumień i kultywowania wspólnych wartości. Chodzi tu m.in. o dobre rozeznanie, co katolicy mogą wspólnie dzielić z imigrantami, a czego nie mogą, w nawiązaniu do muzułmańskiej doktryny, praktyki i nauczania moralnego ${ }^{115}$. Tę samą zasadę należy zastosować do wyznawców innych religii.

Chrześcijan i wyznawców islamu łączy wiara w Boga stworzyciela, codzienna modlitwa, post, jałmużna, pielgrzymowanie, podejmowanie ascezy, walka z niesprawiedliwością i przemocą. Jednocześnie należy zauważać różnice w zakresie: świadomości wobec fundamentalnych swobód, nienaruszalnych praw osoby ludzkiej, równiej godności kobiety i mężczyzny, demokratycznych zasad sprawowania władzy i laickiego charakteru państwa ${ }^{116}$. Wychodząc od świadomości, co do własnej tożsamości, katolicy powinni wspomagać imigrantów w ich zakorzenianiu się w kraju docelowym. Świadectwo wiary, wyżej już wskazane, nie jest udziałem tylko pojedynczych osób, ale również ruchów i stowarzyszeń kościelnych ${ }^{117}$.

\section{Nowe media a misyjność Kościoła}

Oczywistym jest stwierdzenie, że środki społecznego przekazu odgrywają olbrzymią rolę w dzisiejszym społeczeństwie, zwłaszcza są to: prasa, kino, radio, telewizja i Internet. Kościół katolicki w wielu dokumentach Magisterium wypowiadał się na temat środków

\footnotetext{
${ }^{114}$ Por. Erga migrantes caritas Christi, nr 64.

${ }^{115}$ Por. tamże, nr 65.

${ }^{116}$ Por. tamże, nr 66.

${ }^{117}$ Por. tamże, nr 60.
} 
komunikacji ${ }^{118}$. Mass media stanowią dla Kościoła, jakby „pierwszy areopag" współczesnego świata, który jednoczy ludzkość i czyni z niej tzw. „światową wioskę" ${ }^{\prime 11}$. Z oczywistych racji, wspólnota kościelna wykorzystuje je w swojej misji ewangelizacyjnej. Głosząc Ewangelię, Kościół uznaje, że do jego obowiązków należy proklamacja orędzia zbawienia, również za pomocą środków społecznego przekazu oraz formacja do ich wykorzystania ${ }^{120}$.

Ewangelizacja korzysta z każdego godziwego środka, więc i z mass mediów. W tym z tzw. nowych mediów, czyli ze środków komunikacji funkcjonujących w dużej mierze w oparciu o łączność elektroniczną. Dotyczy to ogólnie rozumianego Internetu, ale i innych narzędzi, jak radio oraz telewizja internetowa, czy prasa on-line i oczywiście portale społecznościowe. Nauczanie kościelne nt. środków komunikacji społecznej należy odnieść także do misyjnego oddziaływania, co stanowi nowe i aktualne wyzwanie. Nie tylko w obrębie wewnętrznej komunikacji w Kościele, ale także do komunikowania się na zewnątrz, w tym z migrantami.

Na fakt nowych horyzontów misyjnych wskazywał Jan Paweł II. $\mathrm{W}$ encyklice poświęconej misjom zauważył, że pojawiły się nowe

\footnotetext{
${ }^{118}$ Magisterium Kościoła na temat środków społecznego przekazu, por. ConCILIUM VATiCANum II, Decretum Inter mirifica, 04.12.1963, AAS 56(1964), s. 145-157; Pontificium Consilium Instrumentis Communicationis Socialis, Instructio pastoralis Communio et progressio, 23.05.1971, AAS 63(1971), s. 593-656; TenżE, Instructio Pastoralis Aetatis novae, 22.02.1992, AAS 84(1992), s. 447-468; PAPIESKa Rada Ds. Środków SpoŁecznego Przekazu, Etyka w środkach społecznego przekazu, 04.06.2000, L’Osservatore Romano (pol) 4(2001), s. 48-56; TenżE, Kościót a Internet, 22.02.2002, Wiadomości KAI (10.03.2002), s. 31-35; TenżE, Etyka $w$ Internecie, 22.02.2002, Wiadomości KAI (17.03.2002), s. 31-35.

${ }^{119}$ Por. Aetatis novae, nr 1.

${ }^{120}$ Por. Inter mirifica, nr 3, nr 13. Por. także A. DomAszk, Media - nowe drogi ewangelizacji w nauczaniu Kościoła i w prawie kanonicznym, w: Media - wartości - prawo, red. R. Sztychmiler, Olsztyn 2008, s. 17-37; Tenże, Środki komunikacji społecznej w nauczaniu Kościoła i misji ewangelizacyjnej, Seminare 34 (2013), s. 81-95; TenżE, Katolickie radio internetowe w myśli teologiczno-prawnej Kościoła, Prawo i Kościół 6 (2014), s. 141-168; Tenże, Katolicka telewizja internetowa w myśli teologicznej Kościoła, Prawo Kanoniczne 60(2017) nr 3, s. 107-134.
} 
zjawiska, które również domagają się ewangelizacji, a wśród nich migracje ludności. Następnie wskazywał, że nowym horyzontem misyjnym jest przestrzeń środków społecznego przekazu. Mas media osiągnęły tak wielkie znaczenie, że dla wielu ludzi są głównym źródłem informacji i formacji, stanowią przewodnik i natchnienie dla zachowań indywidualnych, rodzinnych, społecznych, zwłaszcza dla nowych pokoleń, które dorastają w świecie uwarunkowanym przez mass-media ${ }^{121}$. Ta myśl odniesiona do świata mass mediów, jako przestrzeni misyjnej, dotyczy zwłaszcza Internetu. Na co wskazywał zapis z dokumentu z 2002 r. Kościół a Internet, że sieć internetowa ma zastosowanie w ,ewangelizacji, w tym zarówno reewangelizacji, nowej ewangelizacji, jak i tradycyjnie misyjnej posłudze ad gentes (...)"122.

Głoszenie Jezusa Chrystusa i Jego Ewangelii nie dokonuje się więc jedynie w odległych krajach i miejscach geograficznych, postrzeganych jako misyjne. Wszędzie tam, gdzie dociera sieć internetowa, staje się możliwym głoszenie Dobrej Nowiny. Sama komunikacja nie zastąpi jednak realnej wspólnoty wiernych, z jej sakramentami i bezpośrednim proklamowaniem Ewangelii. Najważniejsze znaczenie komunikacji elektronicznej w działalności misyjnej Kościoła dotyczy etapu preewangelizacji.

Jan Paweł II stwierdził, że wspólnota chrześcijańska winna przemyśleć, jak pomóc tym, którzy po raz pierwszy stykają się z chrześcijaństwem. Jak takie osoby przeprowadzić ze świata wirtualnego do rzeczywistej wspólnoty chrześcijańskiej ${ }^{123}$ ? Komunikacja elektroniczna może pomóc zarówno w przygotowaniu na spotkanie z Chrystusem we wspólnocie, czy w stawianiu pierwszych kroków na drodze wiary $^{124}$. Nieco w inny sposób tę myśl kontynuował Benedykt XVI w orędziu na Dzień Środków Społecznego Przekazu z 2010 r. „Nowe

\footnotetext{
${ }^{121}$ Por. Jan PaweŁ II, Redemptoris missio, nr 37.

${ }^{122}$ Kościół a Internet, nr 5; por. A. DomAszK, Możliwości zastosowania Internetu w misji Kościoła, s. 150-157.

${ }^{123}$ Por. Jan PAweŁ II, Orędzie na Światowy Dzień Środków Społecznego Przekazu, 24.01.2002, w: Orędzia papieskie na Światowe Dni Komunikacji Społecznej 19672002, red. M. Lis, Częstochowa 2002, s. 240-246, nr 3.

${ }^{124}$ Por. tamże.
} 
środki umożliwiają nawiązanie kontaktu z wyznawcami wszystkich religii, z niewierzącymi i przedstawicielami różnych kultur, toteż duszpasterstwo w świecie cyfrowym musi pamiętać także o tych, którzy nie wierzą, są zniechęceni, a w sercu mają pragnienie absolutu i nieprzemijającej prawdy" 125 . Myśląc o ewangelizacji należy w cybersieci tworzyć miejsca spotkania i modlitwy dla tych, którzy Boga jeszcze nie znają lub nie znają objawienia chrześcijańskiego.

Preewangelizacja poprzedza formalne rozwiązanie, jakim jest katechumenat. Chodzi o tzw. prekatechumenat, już wyżej zasygnalizowany. Wstępna ewangelizacja prowadzi do wiary i drogi nawrócenia, aby pójść za Chrystusem. Mając to na uwadze, należy zauważyć tych spośród niewierzących, jak i niekatolików, którzy szukają w Internecie informacji o Kościele katolickim, zazwyczaj nie mając żadnych związków ze strukturami kościelnymi. Czynią to niezależnie od tego, czy mieszkają na tzw. terenach misyjnych, czy też w krajach, gdzie większość stanowią chrześcijanie.

Okazją do prezentacji Kościoła jest komunikowanie życia kościelnego, tak wielkich jak i mniej doniosłych wydarzeń, np. pielgrzymek papieskich, czy z życia poszczególnej parafii. Stąd przekaz informacyjny powinien uwzględniać powszechnie zrozumiały język, nie tylko ten „teologiczny”, nie do końca jasny dla współczesnych. Również należy pamiętać o zasadach public relations w praktyce medialnej. A skoro komunikację elektroniczną współtworzą różne osoby, nie tylko dziennikarze, to w nowym świetle należy spojrzeć na normę prawa kanonicznego. Chodzi o to, że wszyscy wierni, na miarę swojej wiedzy i odpowiedzialności, powinni wnosić swój udział w dzieło misyjne $^{126}$. Respektując należne zadania każdego: Biskupa Rzymu, Kolegium Biskupów, poszczególnych biskupów, osób konsekrowanych, misjonarzy i katechistów, w przestrzeni Internetu również pojedynczy katolik przyczynia się do preewangelizacji. Nie zawsze chodzi o ewangelizację bezpośrednio akcentowaną. Częściej będzie

\footnotetext{
${ }^{125}$ Benedy $\mathrm{x}$ XVI, Orędzie na Światowy Dzień Środków Społecznego Przekazu, 24.01.2010, L'Osservatore Romano (pol.) 3-4 (2010), s. 6-7.

${ }^{126}$ Por. KPK 1983, kan. 781.
} 
to zwykłe świadectwo, przyznawanie się do Jezusa, powoływanie się na Pismo Święte, odniesienie do prawdy, choćby przez wpisane posty przy okazji różnych dyskusji na forach internetowych, prowadzone katolickie strony www, blogi i wiele innych możliwości, które sieć internetowa daje. A to wszystko może stać się przy okazji pierwszą lub kolejną katechezą misyjną.

Rzecz jasna przestrzeń cyfrowa nie wyprze fizycznych form pracy duszpasterskiej i misyjnej, ani konieczności doświadczenia wspólnoty wierzących, ale jedynie je uzupełnia ${ }^{127}$. W pracy misyjnej konieczne jest świadectwo misjonarza. Internauta, który szuka prawdy w Kościele, powinien nie tylko znaleźć stronę instytucji kościelnych, np. diecezji, tam gdzie mieszka, czy podstawowe dane adresowe. Należy postawić tezę, że użytkownik Internetu, także imigrant w nowym kraju, może oczekiwać świadectwa wiary katolików, publikujących się na stronach chrześcijańskich, a nawet tych prywatnych. $Z$ tego płynie wniosek, że opracowanie stron katolickich www, czy profili na portalach społecznościowych, nie może być jedynie zamieszczeniem suchych informacji o osobach, strukturach, instytucjach itp.

Akcja misyjna jest dialogiem. Skoro Internet daje wiele możliwości „dialogowania”, to również misjonarze=katolicy przez świadectwo życia i słowa stwarzają okazje do dialogu z niewierzącymi w Chrystusa, w sposób przystosowany do ich mentalności i kultury, i otwierają drogi prowadzące do Chrystusa ${ }^{128}$. Ta swoista „rozmowa” katolika z niewierzącymi, użytkownikami sieci, z zasady ma szanować odmienność mentalności oraz kultury drugiej strony tego spotkania, uwzględniać miłość i pokorę strony chrześcijańskiej. Możliwości sieci pozwalają konfrontować się z osobami, które nie tylko, że nie wierzą, ale wręcz otwarcie krytykują wiarę chrześcijańską i wspólnotę wierzących. Ta sytuacja tym bardziej domaga się świadectwa wiary i nowej apologetyki. Dialog misyjny, jak już wyżej zaznaczono w tej pracy, otwiera się na inkulturację. Zapośredniczony elektronicznie dialog może się też stać spotkaniem międzyreligijnym. W każdej

\footnotetext{
127 Por. P. WięCEK, Inkulturacja przez Internet, W Drodze 4 (2003), s. 29-30.

${ }^{128}$ Por. KPK 1983, kan. $787 \S 1$.
} 
takiej sytuacji spotkania, katolicy ukazują swoją tożsamość, nie zacierając tego, kim są, bez synkretyzmu. W komunikacji elektronicznej Internet pozwala osobom na przekazanie podstawowych informacji na temat swojej kultury, także chrześcijańskiej.

Dostrzeżenie działalności misyjnej, możliwej w pewnej mierze w cyberprzestrzeni, zaciera granice i odległości, ale i stawia nowe wymagania. Na poziomie Kościoła partykularnego istnieje obowiązek wyznaczenia osób i struktur odpowiedzialnych za animację misyjną. Ten obowiązek kanoniczny należy powiązać z funkcjonowaniem portali diecezjalnych i profili w mediach społecznościowych. Tak, aby wzbogacać je o treści, które będą adresowane do osób niewierzących, pochodzących z innych religii oraz do migrantów. Należy też propozycję medialną rozszerzyć o informacje i inne materiały przygotowane w różnych językach, a przynajmniej w języku angielskim. Koresponduje to także z zaleceniem, aby Konferencje Episkopatów inicjowały poczynania, dzięki którym przybysze z terenów misyjnych doznawaliby braterskiego przyjęcia i wsparcia ${ }^{129}$.

Zapewne treść wielu portali www oraz mediów społecznościowych koresponduje $\mathrm{z}$ tematyką ewangelizacją. Przykładowo na polskim gruncie można wskazać na: Komisję Episkopatu Polski ds. Misji (Dzieło Pomocy Ad Gentes, Centrum Formacji Misyjnej, fundacja MIVA) ${ }^{130}$, Papieskie Dzieła Misyjne ${ }^{131}$; portale instytutów życia konsekrowanego i stowarzyszeń życia apostolskiego: Zakon Braci Mniejszych Polskiej Prowincji ${ }^{132}$, Salwatoriański Referat Misji Zagranicznych ${ }^{133}$, misje sercanów ${ }^{134}$, misjonarzy werbistów ${ }^{135}$, misje kapucynów ${ }^{136}$, Salezjański Wolontariat Misyjny w Krakowie oraz Salezjański

\footnotetext{
129 Por. tamże, kan. 792.

${ }^{130}$ Por. http://www.misje.pl/ [dostęp 26.11.2018].

${ }^{131}$ Por. http://www.missio.org.pl/pontyfikat/ [dostęp 26.11.2018].

${ }^{132}$ Por. http://www.misje-ofm.pl/ [dostęp 26.11.2018].

${ }^{133}$ Por. http://misje.sds.pl/ [dostęp 26.11.2018].

${ }^{134}$ Por. http://www.misje.scj.pl/default.htm [dostęp 26.11.2018].

${ }^{135}$ Por. http://www.werbisci.pl/index.php [dostęp 26.11.2018].

${ }^{136}$ Por. http://misje.kapucyni.eu/ [dostęp 26.11.2018].
} 
Ośrodek Misyjny w Warszawie ${ }^{137}$ itd. Zarazem pozostaje aktualne wyzwanie misyjne dla wielu innych portali np. diecezjalnych, czy instytucji katolickich.

\section{Wnioski}

W podsumowaniu, po pierwsze należy podkreślić, że wobec nowych wyzwań dla misji ad gentes pierwszoplanowa jest świadomość. To jest, że misje katolickie nie dokonują się jedynie w odległych krajach, ale że poprzez obecność migrantów oraz dostęp do nowych środków komunikacji zbliżyła się perspektywa misyjna do krajów tradycyjnie chrześcijańskich. Już nie jest to tylko odpowiedzialność misjonarzy, którzy poświęcają się pracy misyjnej daleko od swojej ojczyzny. Każdy katolik w przestrzeni swojego codziennego życia ma okazję być misjonarzem dla swoich sąsiadów=migrantów albo współużytkowników odwiedzanego portalu lub strony społecznościowej w Internecie. To są nowe wyzwania dla ogólnie rozumianego Kościoła, ale i dla poszczególnych wiernych, by dzielili się wiarą.

W dalszej kolejności należy wskazać na potrzebę przemyślenia, a następnie budowania struktur i rozwiązań, na poziomie Kościoła powszechnego, partykularnego, a także najmniejszej parafii czy innej wspólnoty wiernych. Tak, aby orędzie chrześcijańskie mogło dotrzeć do każdego migrującego człowieka, również do każdego poszukującego prawdy - użytkownika Internetu. O ile normy prawa powszechnego wydają się być względnie wystarczające dla całego Kościoła. To otwiera się perspektywa poszukania nowych pomysłów i ich unormowania w Kościele partykularnym. Ta przestrzeń wymaga dalszych poszukiwań naukowych, pastoralnych i kanonistycznych.

Jako kierunkową należy też przywołać myśl Jana Pawła II, że duch misyjny splata się z powszechnym wezwaniem do świętości: „Powołanie misyjne ze swej natury wypływa z powołania do świętości Każdy misjonarz jest autentyczny jedynie wówczas, gdy wchodzi na drogę świętości. (...) Powszechne powołanie do świętości jest ściśle związane z powszechnym powołaniem do działalności misyjnej: każdy wierny

\footnotetext{
${ }^{137}$ Por. https://swm.pl/, http://misjesalezjanie.pl/ [dostęp 26.11.2018].
} 
powołany jest do świętości i do działalności misyjnej. (...) Duchowość misyjna Kościoła prowadzi do świętości” ${ }^{138}$.

A myśląc o nowych wyzwaniach dla misyjności Kościoła w kontekście europejskim nie można zapomnieć o nadziei chrześcijańskiej. Chrześcijańskie dziedzictwo, którym należy się dzielić z każdym człowiekiem, nie należy wyłącznie do przeszłości Europy. Przeciwnie, jest to program dla przyszłości i rozwoju tego kontynentu ${ }^{139}$.

\section{Ad gentes missions and new challenges}

The Catholic Church is obliged to proclaim the Gospel of Jesus Christ. It is a missionary order directed to all people (ad gentes). Canon law perceives new situations: many migrations of people, including non-Christians, and the widespread influence of mass media, as new missionary challenges. The study aimed to investigate how Church law adapts to these new situations. The first chapter outlines what the ad gentes missions are. The next chapter presents the phenomenon of contemporary migration and the Church's response to this situation, especially to non-Christians in the European environment. Then the study outlined the situation of the so-called new media, their impact, and evangelization undertaken by the people of the Church in this area.

In summary, it should be emphasized that awareness is the priority for the new challenges for ad gentes missions. Catholic missions do not take place only in distant countries, but through the presence of migrants and access to new means of communication, the missionary perspective has approached traditionally Christian countries. Every Catholic in the space of his daily life has the opportunity to be a missionary for his neighbours = migrants or co-users of the portal visited on the Internet. We need to think about the new solutions of the universal, particular or the smallest parish, so that the Christian message can reach every migrating person, including the Internet user. One should look for new ideas and their norms in the particular Church.

\footnotetext{
${ }^{138}$ Jan PaweŁ II, Redemptoris missio, nr 90.

139 TenżE, Ecclesia in Europa, nr 120.
} 
SŁowA KLUCzowe: migracja; mass media; misje, ad gentes; Kościół; prawo kanoniczne

KEYWORDS: the migration; mass media; missions; ad gentes; the Church; the canon law

\section{NOTA O AUTORZE}

ks. Dr hab. Arkadiusz Domaszk SDB, Prof. UCZelni - pracownik naukowo-dydaktyczny na Wydziale Prawa Kanonicznego UKSW w Warszawie, wykładowca w Wyższym Seminarium Duchownym SDB w Krakowie. Zainteresowania naukowe: prawo o posłudze nauczania, mass media a prawo kanoniczne, dobra doczesne Kościoła, prawo wyznaniowe i prawo zakonne. 